\title{
Implikasi Erupsi Gunung Agung Terhadap Sosial Ekonomi Pelaku Pariwisata di Kelurahan Ubud, Kecamatan Ubud, Kabupaten Gianyar,Bali
}

I Kadek Diana Putra a,1 Luh Putu Kerti Pujani a,2

1dianaputra11@gmail.com ${ }^{2}$ kerti_pujani@unud.ac.id

a Program Studi Sarjana Destinasi Pariwisata, Fakultas Pariwisata, Universitas Udayana, Jl. Dr. R. Goris, Denpasar, Bali 80232 Indonesia

\section{Abstract}

Mount Agung eruption has a significant influence on the tourism sector. The tourism sector becomes the main sector of the Ubud community. This study aims to determine the implications of Mount Agung eruption on socioeconomic tourism actors in the village of Ubud in the accommodation and restaurant business. This research is important to do because it is useful for tourism actors who are directly involved in the tourism sector so that it can deal with natural phenomena that unpredictable events occur.

The research method in this report is using qualitative and quantitative data types. Sources of data used are primary and secondary data. Data collection techniques used are observation, interview, and documentation. Informant determination technique used is purposive sampling. Data analysis used is descriptive qualitative. The first thing to do is to observe for social phenomena and then to categorize the information obtained, then explain the categorization, then explain the categorization relationship and draw the general conclusion.

The results of this research indicate that the implications of the Gunung Agung eruption on socio-economic tourism actors in Ubud Village include occupation of accommodations, restaurant visits, shortening employee work hours, employee income, employee welfare, family employee education investment, additional employee work that work in accommodation restaurant business.

\section{PENDAHULUAN}

Pariwisata merupakan sektor industri yang mampu menggerakan pertumbuhan perekonomian dan pembangunan. Pariwisata juga dipandang sebagai salah satu industri multidimensi yang memiliki karakter ekonomi, sosial, budaya, fisik, dan politik serta sebagai industri terbesar dan mengalami pertumbuhan paling cepat di dunia saat ini (Sunarta, 2015). Industri pariwisata di Indonesia menjadi salah satu industri besar dan sektor jasa dengan tingkat pertumbuhan paling pesat di dunia saat ini. Bahkan dewasa ini, sektor pariwisata menduduki posisi kedua dalam penerimaan devisa negara setelah minyak dan gas. Industri pariwisata merupakan industri yang dikembangkan dan dihandalkan sebagai salah satu sektor pendorong pertumbuhan ekonomi, karena sektor pariwisata berpengaruh signifikan terhadap perekonomian masyarakat seperti meningkatkan kesejahteraan.

Pariwisata dipandang sebagai industri yang kompleks karena dalam industri pariwisata terdapat industri-industri yang berkaitan. Industri pariwisata terdiri dari usaha-usaha diantaranya: jasa transportasi, biro perjalanan, akomodasi, jasa makanan dan minuman, penyelenggaraan hiburan hingga usaha spa. Berkembangnya usaha-usaha pariwisata mampu membuka lapangan pekerjaan baru serta dapat mengurangi pengangguran. Usaha tersebut yang kemudian dijadikan sebagai sumber pendapatan bagi masyarakat lokal ataupun sekitarnya, sehingga mampu untuk meningkatkan taraf perekonomian. Namun, kergantungan yang hanya bertumpu pada sektor pariwisata akan menyebabkan efek yang negatif karena sektor pariwisata merupakan suatu industri yang rentan terhadap bencana khususnya bencana alam.

Bencana alam merupakan suatu peristiwa yang mampu mengancam ataupun mengganggu kehidupan masyarakat yang disebabkan oleh alam diantaranya berupa tsunami, gempa bumi, angin topan, tanah longsor, banjir, kekeringan, dan erupsi. Belakangan ini, industri pariwisata di Bali mengalami degradasi akibat terjadinya erupsi Gunung Agung. Aktivitas Gunung Agung pada tanggal 18 September 2017 lalu, statusnya meningkat menjadi level III (siaga), dimana aktivitas gempa tektonik semakin menguat berdasarkan pengamatan visual dan instrumental. Empat hari setelah status Gunung Agung siaga kemudian statusnya ditingkatkan menjadi awas. Semenjak ditetapkan menjadi status awas, banyak informasi yang beredar di berbagai media masa mulai dari media cetak, sosial media ataupun melalui web. Erupsi Gunung Agung tidak hanya membuat masyarakat khawatir 
namun juga dari kalangan pemerintah, pengusaha dan wisatawan pun ikut merasakan kekhawatiran tersebut. Aktivitas dari erupsi Gunung Agung juga sempat menyebabkan terjadinya penutupan Bandara Internasional I Gusti Ngurah Rai selama tiga hari sejak tanggal 27 November 2017 hingga 30 November 2017. Penutupan Bandara tersebut mengakibatkan tidak sedikit calon wisatawan Nusantara maupun Mancanegara yang membatalkan kunjungannya ke Bali.

Pulau Bali masih menjadi destinasi favorit dan tidak dipungkiri bahwa Bali masih menjadi tujuan utama pariwisata di Indonesia. Perkembangan pariwisata di Bali sejalan dengan pesatnya perkembangan industriindustri pariwisata yang tersebar di kawasankawasan stategis pariwisata. Namun, citra pariwisata Bali dianggap tidak aman karena adanya erupsi Gunung Agung. Salah satu kawasan strategis yang industri pariwisatanya berkembang dan terkena dampak dari erupsi yaitu Kawasan Pariwisata Ubud.

Meskipun Ubud tidak terkena dampak material dari erupsi Gunung Agung, namun terjadinya penutupan bandara menjadi salah satu faktor yang mengakibatkan kemunduran industri pariwisata di Ubud yakni pada usaha akomodasi dan restoran. Dari kemunduran usaha akomodasi dan restoran tersebut, maka tidak dipungkiri bahwa akan berimplikasi juga kepada tenaga kerja di usaha akomodasi ataupun restoran. Maka dari itu, menarik untuk dilakukan penelitian karena sedang hangat diperbincangkan dan relevan untuk dikaji seberapa jauh implikasi erupsi Gunung Agung dalam akomodasi dan restoran.

\section{TINJAUAN PUS TAKA}

Adapun tiga telaah hasil penelitian sebelumnya yang berkaitan dengan penelitian ini. Telaah hasil penelitian sebelumnya yang pertama berkaitan dengan dampak erupsi Gunung Sinabung terhadap pendapatan di sektor pariwisata yaitu penelitian yang dilakukan oleh Febrianty (2016). Telaah penelitian kedua berkaitan dengan pengaruh erupsi terhadap industri pariwisata yaitu penelitian yang dilakukan oleh Rahmawati (2014). Telaah penelitian ketiga yaitu terkait motivasi perempuan sebagai pengelola pondok wisata di Kelurahan Ubud oleh Sri (2013).
Dalam tulisan ini menggunakan beberapa konsep untuk menganalisis permasalahan, yaitu konsep implikasi (Islamy, 2003), konsep pariwisata dan bencana (Rindrasih dan Mujiasih, 2015), erupsi (Bronto, 2001), konsep Pelaku pariwisata (Damanik dan Weber, 2006), serta konsep kesejahteraan (Nasikun, 1993 dalam Rosni 2017 dan Badan Pusat Statistik, 2013),

\section{METODE}

Data yang digunakan dalam penelitian ini bersumber dari data primer dan data sekunder. Data primer yang dimaksud yaitu tentang data tingkat hunian akomodasi, jumlah kunjungan ke restoran, pemendekan jam kerja karyawan, pendapatan karyawan dan kesejahteraan karyawan, investasi pendidikan anak karyawan, dan pekerjaan tambahan dalam keluarga karyawan. Sedangkan, data sekunder yang dimaksud yaitu mengenai Profil Kelurahan Ubud.

Teknik pengumpulan data yang digunakan dalam penelitian ini adalah observasi, wawancara dan dokumentasi. Observasi dilakukan untuk mendapatkan gambaran yang jelas tentang kondisi usaha akomodasi dan restoran di Kelurahan Ubud. Wawancara dilakukan untuk mengetahui lebih dalam apa saja implikasi erupsi Gunung Agung terhadap sosial Ekonomi pelaku usaha akomodasi dan restoran di Kelurahan Ubud. Data jumlah usaha akomodasi dan restoran di Kelurahan Ubud dan foto-foto dari akomodasi serta restoran diperoleh dari dokumentasi.

Teknik analisis yang digunakan dalam penelitian ini adalah analisis kualitatif. Adapun teknis analisis data yang dimaksud adalah sebagai berikut. 1) melakukan pengamatan terhadap suatu fenomena sosial ekonomi, kemudian melakukan identifikasi, revisi-revisi, dan pengecekan ulang terhadap data yang terdapat di lapangan. 2) melakukan kategorisasi terhadap informasi yang diperoleh saat penelitian, 3) menelusuri serta kemudian menjelaskan kategorisasi tersebut, 4) menjelaskan hubungan-hubungan kategorisasi, dan 5) menarik kesimpulankesimpulan umum dari hasil penelitian yang telah dilakukan (Bungin, 2007). Dalam hal ini, peneliti mengamati fenomena sosial ekonomi yang terjadi di usaha akomodasi dan restoran yang ada di Kelurahan Ubud saat erupsi 
Gunung Agung, kemudian mengindentifikasi implikasi erupsi Gunung Agung terhadap sosial ekonomi pelaku usaha akomodasi dan restoran di Kelurahan Ubud, selanjutnya mengkatagorikan informasi yang diperoleh serta menjelaskan kategori tersebut, kemudian menghubungan kategori tersebut dan menarik kesimpulan sebagai jawaban analisis.

\section{HASIL DAN PEMBAHAS AN}

Adapun hasil dan pembahasan dalam tulisan ini dapat dijelaskan sebagai berikut.

\subsection{Gambaran Um um Kelurahan Ubud}

Penelitian ini dilakukan di Kelurahan Ubud, Kecamatan Ubud, Kabupaten Gianyar. Secara geografis, Kelurahan Ubud berada dalam jarak $12 \mathrm{~km}$ yang dapat ditempuh dalam waktu 30 menit dari ibu kota Gianyar. Sedangkan jarak tempuh Kelurahan Ubud dengan Bandara I Gusti Ngurah Rai yaitu berjarak 45 Kilometer dan dapat ditempuh dengan 1 jam 30 menit perjalanan. Kelurahan Ubud berada di jantung Kecamatan Ubud yang dikenal sebagai pusat pariwisata di Kabupaten Gianyar. Luas wilayah Kelurahan Ubud adalah 92 Hektare atau $7,8 \mathrm{Km}^{2}$. Dari luas wilayah tersebut dan ditunjang dengan kondisi topografi seperti di atas, pemanfaatan lahan di wilayah Kelurahan Ubud telah mengalami perkembangan yaitu Areal Persawahan 360 Hektare, Areal Pekarangan 213,27 Hektare, Tanah Tegalan 140,34 Hektare, dan Lain-lain 66,31 Hektare (Profil Kelurahan Ubud, 2015). Kelurahan Ubud merupakan satu-satunya Kelurahan yang ada di di Kecamatan Ubud.

Berdasarkan profil Kelurahan Ubud tahun 2015, bahwa Kelurahan Ubud terletak di Kecamatan Ubud, Kabupaten Gianyar. Dengan jumlah penduduk mencapai 12.145 jiwa yang terbagi menjadi 6.047 orang perempuan dan 6.098 orang laki-laki.

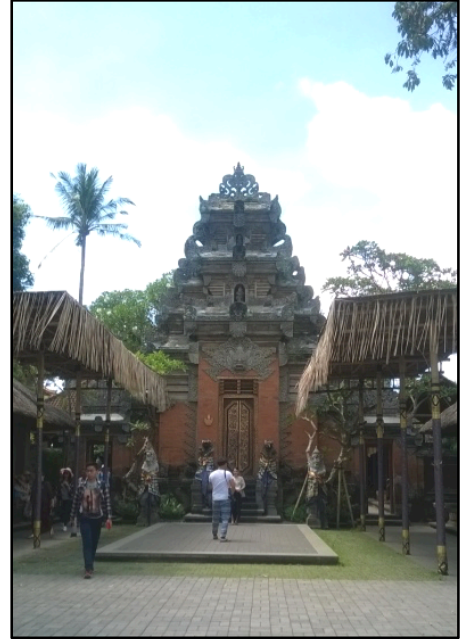

Gambar 1. Kondisi Puri Saren Ubud Pasca Erupsi Gunung Agung

Sumber: Dokumentasi Penelitian, 2018

\subsection{Implikasi Erupsi Gunung Agung Terhadap Sosial Ekonomi Pelaku Usaha Akomodasi dan Restoran di Kelurahan Ubud}

Kepariwisataan Ubud dimulai sekitar tahun 1928 ditandai dengan hadirnya tokohtokoh asing seperti: Rudolf Bonnet seorang pelukis Belanda dan Walter Spies yang seorang pelukis asal Jerman yang banyak memberi pengaruh terhadap corak kehidupan seni lukis Bali, khususnya di Desa Ubud dan sekitarnya (Pujani, 1981). Kunjungan wisatawan semakin banyak, membuat perkembangan pariwisata di Ubud semakin pesat. Pada tahun 1960 mulai bermunculan berbagai fasilitas pariwisata berupa hotel dan restoran. Memasuki permulaan tahun 1990, Bupati Gianyar atas nama Cokorda Gde Budi Suryawan yang juga merupakan tokoh dari Puri Ubud, banyak mendorong pembangunan fasilitas pariwisata di Ubud berupa hotel maupun restoran dan berkembang pesat hingga saat ini. Akan tetapi, pariwisata di Kelurahan Ubud mengalami degradasi (kemunduran) saat terjadi erupsi Gunung Agung pada tahun 2017. 


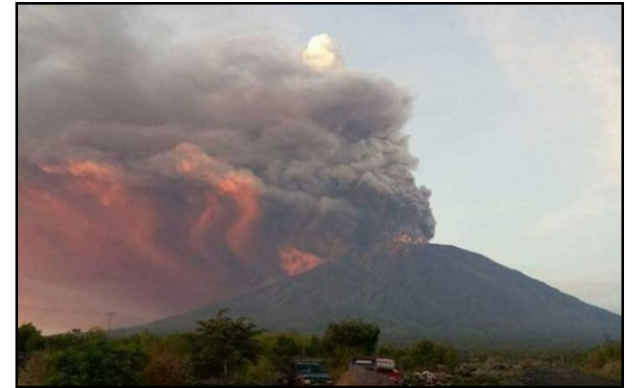

Gambar 2. Erupsi Gunung Agung

Sumber: www.tribunnews.com

Beberapa implikasi yang ditimbulkan dari erupsi Gunung Agung terhadap sosial ekonomi pelaku pariwisata di Kelurahan Ubud khususnya pada usaha akomodasi dan restoran yaitu Tingkat hunian pada akomodasi, kunjungan ke restoran, pemendekan jam kerja, pendapatan karyawan, kesejahteraan karyawan, investasi pendidikan keluarga karyawan, dan pekerjaan tambahan karyawan yang kemudian dapat dijelaskan sebagai berikut.

\section{a. Tingkat Hunian Pada Usaha Akomodasi di Kelurahan Ubud}

Tingkat hunian pada akomodasi penting bagi pelaku di dalamnya baik itu dari pihak manajemen ataupun karyawan karena sebagai pemasukan bagi usaha akomodasi. Semakin tinggi tingkat hunian maka semakin banyak juga pemasukan yang diterimanya. Tingkat hunian juga bergantung pada musiman yaitu: low season, high season, dan pick season. Low season umumnya terjadi pada awal tahun, high season pada awal juni hingga akhir tahun dan pick season biasanya pada bulan Agustus. Akan tetapi, fenomena erupsi Gunung Agung dipengujung tahun 2017 (mulai tanggal 12 September 2017) tak pelak mengakibatkan dampak penurunan kunjungan wisatawan ke Bali. Pada saat ditetapkan status awas pertama kalinya di akhir bulan September 2017, tingkat hunian hotel langsung mengalami penurunan (Arida, 2017). Begitu juga tingkat hunian pada akomodasi khususnya di Kelurahan Ubud yang mengalami penurunan akibat terjadinya erupsi Gunung Agung.

Wisatawan yang menginap di Ubud rata-rata selama tiga malam, akan tetapi saat terjadinya erupsi Gunung Agung, tidak sedikit terdapat wisatawan yang memperpendek waktunya untuk menginap menjadi satu malam atau dua malam saja. Bahkan yang awalnya satu minggu menjadi dua atau tiga hari saja. Di samping itu, masifnya berita yang kurang akurat (hoak) di media online membuat wisatawan menjadi lebih takut untuk tinggal di Ubud dan akhirnya memilih untuk ke luar dari Ubud untuk ke Bali Selatan seperti Sanur karena jaraknya lebih jauh dari Gunung Agung.

Tingkat hunian hotel melati mengalami penurunan sejak bulan Oktober 2017 hingga Februari 2018. Padahal sebelum itu, tingkat hunian hotel melati selalu di atas $50 \%$ dan bahkan mencapai 90\%. Akan tetapi, pasca erupsi Gunung Agung bulan September 2017 dan penutupan bandara serta menjamurnya berita yang kurang akurat mengakibatkan penurunan tingkat hunian yang sangat signifikan dan membuat manajemen maupun karyawan harus menerima keadaan tersebut. Terjadinya erupsi, kemusian mengakibatkan penutuan bandara serta tersebar berita yang tidak benar mengakibatkan terjadinya penururunan kunjungan wisatawan serta berpengaruh signifikan terhadap tingkat hunian hotel melati. Bahkan tingkat hunian hotel melati menjadi di bawah $50 \%$, sehingga terdapat banyak kamar-kamar yang kosong. Penurunan tingkat hunian hotel melati mencapai 50\%.

Penurunan tingkat hunian hotel melati yang signifikan membuat manajemen hotel melati harus membuat beberapa kebijakan dalam upaya membangkitkan kembali tingkat hunian hotel melati. Upaya yang dilakukan dengan teknik marketing seperti adanya penurunan harga kamar yang mencapai $10 \%$ hingga $20 \%$ perkamar. Selain itu, terdapat juga pemberian fasilitas lain misalnya memberikan towel secara gratis. Selain untuk mengembalikan tingkat hunian, upaya tersebut juga diharapkan mampu untuk memback-up semua pengeluaran hotel melati pada usaha akomodasi termasuk membayar gaji karyawan. Sehingga mampu menciptakan keseimbangan antara pemasukan dan pengeluaran. Selain penurunan tingkat hunian hotel melati, penurunan tingkat hunian juga dialami pondok wisata yang ada di Kelurahan Ubud.

Tingkat hunian pada pondok wisata di Kelurahan Ubud juga mengalami penurunan yang signifikan saat terjadinya erupsi dan 
pasca penutupan Bandara Internasional I Gusti Ngurah Rai. Penurunan tingkat hunian pondok wisata mencapai $100 \%$ atau semua kamar kosong (okupansi 0\%) antara bulan November dan Desember 2017. Okupansi 0\% terjadi selama satu minggu hingga ada yang mencapai dua minggu. Penurunan yang signifikan tersebut membuat pemilik pondok wisata mengambil kebijakan seperti memberikan pekerjaan lain kepada karyawan dan menurunkan harga kamar.

Harga kamar pada pondok wisata di Kelurahan Ubud kisaran Rp. 250.000 hingga Rp. 600.000. Akan tetapi, adanya erupsi Gunung Agung membuat pemilik pondok wisata menurunkan harga kamar hingga 50\% perkamarnya. Penurunan harga kamar mulai kditerapkan bulan November 2017 dan Desember 2017. Hal tersebut dilakukan karena minimnya bookingan dan berharap dengan diturunkannya harga kamar mampu sedikit tidaknya lebih menarik wisatawan untuk menginap. Selain itu, selama penurunan harga tersebut, pemilik pondok wisata tidak memperhitungkan keuntungan namun lebih memikirkan balik modal. Sehingga antara pemasukan dan pengeluaran menjadi balance.

\section{b. Kunjungan ke Restoran di Kelurahan Ubud}

Dalam menarik kunjungan ke restoran, pihak manajemen kerap melakukan kerjasama dengan travel agent, asosiasi dan melakukan promosi baik melalui media cetak maupun media online sehingga mampu menjaga stabilitas kunjungan ke restoran. Akan tetapi, bencana alam yang terjadi pada akhir tahun 2017 yaitu adanya erupsi Gunung Agung membuat kepanikan dan rasa ketidaknyaman bagi wisatawan yang ada di Bali dan yang akan berkunjung ke Bali. Meskipun Ubud tidak terkena dampak langsung dari dari erupsi, wisatawan juga memiliki rasa takut karena kemungkinan tidak bisa balik ke negaranya masing-masing ketika bandara ditutup. Ditambah lagi berita-berita yang tidak akurat menjamur di media online. Akibatnya banyak wisatawan yang cancelation sehingga terjadi penurunan tingkat kunjungan khususnya ke Ubud. Oleh karena itu, kunjungan ke restoran yang ada di Kelurahan Ubud juga ikut menurun.
Penurunan kunjungan ke usaha restoran berlangsung cukup lama yaitu sekitar awal Oktober 2017 hingga Februari 2018. Seharusnya pada akhir tahun merupakan tingkat high season dalam kunjungan ke restoran. Penurunan kunjungan ke restoran mencapai hingga 60\% dari normalnya. Seperti misalnya di Restoran Ibu Rai yang biasanya kunjungan wisatawan mencapai 150 hingga 250 orang. Namun, setelah terjadinya erupsi dan juga penutupan bandara, kunjungan wisatawan menurun signifikan yaitu kisaran 30 hingga 60 orang perharinya. Di samping itu, pasca penutupan bandara juga mempengaruhi presentase kunjungan menjadi rendah. Sehingga pihak manajemen harus melakukan upaya-upaya untuk menyiasati kondisi tersebut.

Penurunan kunjungan wisatawan ke restoran juga mengakibatkan manajemen melakukan kegiatan promosi yang lebih intensif. Salah satu promo yang diberikan yaitu dengan menurunkan atau member diskon harga menu baik menu makanan ataupun minuman. Rata-rata penurunan harga yang diberikan kepada wisatawan yang berkunjung yaitu mencapai $10 \%$ hingga $20 \%$ dari harga normalnya. Selain memberikan penurunan harga menu, manajemen restoran juga membuat special day, happy hours, welcome drink gratis, hadiah bagi pengunjung yang sedang berulang tahun, dan terkadang mengadakan live music. Hal itu dilakukan dengan harapan mampu untuk menarik lebih banyak kunjungan wisatawan ke restoran.

\section{c. Pemendekan Jam Kerja Karyawan pada Usaha Akomodasi dan Restoran di Kelurahan Ubud (Selanjutnya disebut Karyawan Pariwisata Ubud)}

Pemendekan jam kerja merupakan pengurangan waktu (durasi) kerja bagi karyawan yang berkerja di suatu perusahaan. Dalam hal ini, karyawan yang dimaksud yaitu karyawan yang bekerja di usaha akomodasi dan restoran. Pada normalnya, karyawan yang bekerja di restoran dengan durasi 8 jam perhari dan termasuk 1 jam istirahat. Dalam seminggu, karyawan dapat libur (off) selama 1 hari. Jadi, dalam sebulan karyawan normalnya bekerja selama 26 hari dan atau maksimal 27 hari. Karyawan biasanya mendapatkan cuti baik dalam cuti tahunan, cuti bulanan, cuti 
hamil dan cuti sakit. Biasanya jika dalam periode cuti (tahunan atau bulanan) tidak diambil maka cuti tersebut dianggap sudah tidak berlaku lagi. Setiap usaha akomodasi maupun restoran mempunyai kebijakan masing-masing mengenai cuti karyawan dan durasi kerja karyawan.

Berdasarkan hasil penelitian, ditemukan bahwa terdapat pemendekan jam kerja bagi karyawan pada Usaha Akomodasi dan restoran yang ada di Kelurahan Ubud. Terjadinya pemendekan jam kerja berkaitan erat dengan jumlah kunjungan wisatawan ke Ubud yang menurun. Semenjak erupsi Gunung Agung dan setelah Bandara Internasional Ngurah Rai ditutup selamat tiga hari pada 27 hingga 30 November 2017, kunjungan wisatawan mulai merosot dari bulan Oktober 2017 hingga Februari 2018. Menurunnya kunjungan wisatawan ke Ubud tentu juga berakibat minimnya wisatawan yang berkunjung ke restoran dan juga rendahnya tingkat okupansi. Sehingga hal tersebutlah yang membuat manajemen untuk mengambil tindakan yaitu dengan menerapkan pemendekan jam kerja bagi semua karyawan. Pemendekan jam kerja yang terjadi pada Usaha Akomodasi dan restoran di Kelurahan Ubud rata-rata diterapkan pada bulan November 2017 hingga Februari 2018.

Karyawan yang bekerja di restoran, biasanya bekerja selama 26 hari atau 27 hari perbulan. Akan tetapi, setelah terkena pemendekan jam kerja durasi karyawan bekerja yaitu menjadi 13 hari atau 14 hari saja perbulan atau sering disebut $50 \%$ kerja dan $50 \%$ tidak kerja. Dalam hal ini, untuk durasi jam kerja masih sesuai yaitu selama 8 jam perhari. Pemendekan jam kerja tersebut diambil manajemen dengan beberapa cara diantaranya menekan karyawan untuk mengambil cuti yang sebelumnya belum diambil, mewajibkan mengambil day payment (DP), dan memberikan ekstra off (libur tambahan). Selain itu, pemendekan jam kerja telah melalui mekanisme kesepakatan antara dua belah pihak yaitu karyawan dan manajemen. Pemendekan jam kerja berlaku untuk semua karyawan (staff) kecuali yang training.

Pada pemendekan jam kerja yang diberikan oleh manajemen untuk karyawan restoran yakni dalam sebulan, karyawan hanya bekerja dua minggu dan libur dua minggu. Dalam sebulan karyawan berturutturut libur satu minggu dan bekerja satu minggu. Contohnya minggu pertama libur, minggu kedua kerja, minggu ke tiga libur dan minggu ke empat kerja. Selain itu, ada juga manajemen yang menerapkan dalam seminggu liburnya tiga sampai empat hari yaitu dengan mengambil cutinnya atau day payment (DP) atau libur tambahan sehingga dalam satu bulan karyawan bekerja 13 hari sampai 14 hari.

Pemendekan jam kerja yang diterapkan oleh manajemen yaitu untuk meminimalkan pengeluaran perusahaan dan efisiensi saat bekerja. Pengeluaran yang dimaksud adalah biaya yang dikeluarkan untuk karyawan seperti uang makan. Mengingat kunjungan wisatawan ke restoran yang tidak banyak maka karyawan yang dibutuhkan untuk melayani wisatawan tersebut juga sedikit. Oleh karena itu, kebijakan yang diambil manajemen yaitu pemendekan jam kerja atau bisa disebut pengurangan durasi kerja sebagai solusi untuk menjaga stabilitas perusahaan sehingga tidak akan mengalami kemunduran atau mengalami kebangkrutan.

\section{d. Pendapatan Karyawan Pariwisata Ubud}

Pada usaha akomodasi, khususnya usaha pondok wisata pendapatan yang diterima karyawan sama dengan karyawan lainnya atau tidak ada leveling dalam penerimaan pendapatan. Namun, pada hotel melati dan restoran yang ada di Kelurahan Ubud telah menerapkan sistem leveling untuk pendapatan karyawan. Leveling yang dimaksud berdasarkan pada department, kompetensi, dan lama kerja (senior-junior) karyawan. Hal tersebut merupakan kebijakan dari manajemen untuk semua karyawan dan sebagai apresiasi bagi karyawan yang memiliki nilai lebih dalam bekerja.

Gaji pokok karyawan baik di usaha akomodasi (hotel melati dan pondok wisata) maupun restoran di Kelurahan Ubud belum sesuai dengan UMK yang telah detetapkan oleh Pemda Gianyar. Hal tersebut dikarenakan beberapa pertimbangan seperti: masih rendahnya pemasukan perusahaan sehingga belum mampu memberikan gaji pokok sesuai 
UMK, sudah settingan dari manajemen, dan kompetensi karyawan yang dianggap belum kompeten. Akan tetapi, jika diglobalkan gaji karyawan telah mencapai dan bahkan melebihi UMK yang telah ditetapkan Khususnya untuk di Kabupaten Gianyar.

Beberapa hotel melati dan restoran di Kelurahan Ubud, selain memberikan gaji pokok, uang makan dan uang servis, ada juga yang memberikan bonus dan atau reward sebagai pendapatan tambahan kepada karyawan yang memiliki kompetensi dan progress selama bekerja. Reward untuk karyawan biasanya diberikan satu tahun sekali. Selain itu, bonus yang didapat karena telah mencapai atau melebihi target dari kunjungan wisatawan ke restoran dalam satu bulan. Gaji tambahan juga diterima pada saat hari raya yang sering disebut dengan THR (Tunjangan Hari Raya) yang diberikan pada Hari Raya Nyepi atau Hari Raya Galungan. Sehingga dalam sebulan atau setahun karyawan bisa menerima pendapatan tambahan diluar gaji pokok, uang makan maupun servis.

Pendapatan pada hotel melati dan restoran terdiri dari gaji pokok, uang makan dan uang servis. Gaji pokok merupakan gaji tetap yang diterima karyawan perbulan. Setiap perusahaan memiliki nominal tertentu yang diberikan kepada karyawannya. Berdasarkan hasil penelitian, gaji pokok yang diterima oleh karyawan di hotel melati dan restoran sebesar Rp. $\quad 1.000 .000$ hingga Rp. 1.500 .000 perbulannya. Besaran gaji pokok tersebut tergantung dari perusahaan itu sendiri. Untuk uang makan diberikan Rp. 20.000 perhari kerja, kira-kira perbulannya mendapatkan Rp. 500.000. Di samping itu, uang servis yang diberikan kepada karyawan berdasarkan tingkat okupansi (hunian) hotel melati atau jumlah kunjungan ke restoran. Semakin tinggi tingkat okupansi atau kujungan ke restoran maka semakin besar uang servis yang didapat karyawan. Berbeda halnya dengan karyawan pondok wisata yang gajinya diglobalkan perbulan dan atau ada tambahan bonus dari owner. Akan tetapi, bencana alam (erupsi Gunung Agung) yang menimpa Bali pada September 2017, ditambah lagi dengan penutupan bandara dan berita kurang baik menjamur di media online untuk Bali menyebabkan tingkat kunjungan wisatawan mengalami penurunan, khususnya kunjungan wisatawan ke Ubud yang kemudian berpengaruh terhadap pendapatan karyawan.

Penurunan tingkat kunjungan
wisatawan mengakibatkan tingkat okupansi pada usaha akomodasi dan kunjungan ke restoran turut serta mengalami penurunan. Sehingga pihak manajemen hotel melati maupun restoran membuat kebijakan yaitu memberlakukan pemendekan jam kerja atau pengurangan durasi kerja bagi semua karyawan. Dengan pemendekan jam kerja tersebut membuat gaji yang diterima karyawan menurun. Penurunan gaji karyawan yaitu pada uang makan dan uang servis. Penurunan uang makan karena durasi bekerja karyawan yang lebih sedikit, sedangkan penurunan uang servis karena rendahnya tingkat hunian atau kunjungan ke restoran.

Berdasarkan hasil penelitian, penurunan gaji karyawan mencapai $30 \%$ hingga 50\% dari gaji normalnya. Presentase penurunan gaji karyawan mengacu pada presentase penurunan tingkat hunian akomodasi atau kunjungan ke restoran. Sedangkan, karyawan yang bekerja di pondok wisata, penurunan gaji bergantung pada pemilik pondok wisata (owner). Gaji karyawan pondok wisata perbulan kisaran Rp. 1.500 .000 hingga Rp. 2.000.000. Dari hasil penelitian, gaji yang diterima karyawan pondok wisata ketika pada bulan yang okupansi sangat rendah atau tingkat hunian $0 \%$ adalah dari uang owner sendiri (ditalangi). Gaji total karyawan yang biasanya dihitung perbulan, kemudian dihitung perhari kerja dan karyawan tidak lagi mendapatkan bonus. Pendapatan yang berkurang akan mengganggu pengeluaran sehari-hari karyawan.

\section{e. Kesejahteraan Karyawan Pariwisata Ubud}

Dalam penelitian ini, menunjukan bahwa adanya erupsi Gunung Agung mempengaruhi kesejahteraan karyawan yang bekerja pada usaha akomodasi dan restoran di Kelurahan Ubud khususnya karyawan yang sudah berkeluarga. Adanya erupsi Gunung Agung mengakibatkan tingkat hunian akomodasi dan kunjungan ke restoran menurun. Sehingga pendapatan dari karyawan ikut mengalamai penurunan. Penurunan pendapatan membuat karyawan harus bisa 
memanajemen pengeluaran sehari-hari dengan sebaik-baiknya agar pendapatan perbulan tersebut mampu untuk memenuhi kebutuhan keluarganya. Ada tiga indikator yang dilihat untuk mengetahui implikasi erupsi terhadap kesejahteraan karyawan akomodasi dan restoran di Kelurahan Ubud, yaitu pengaruh terhadap pendidikan, pola konsumsi, dan rekreasi.

Tingkat pendapatan akan mempengaruhi konsumsi karyawan. Dalam kenyataannya menunjukan bahwa pengeluaran konsumsi meningkat dengan naiknya pendapatan dan sebaliknya jika pendapatan turun, pengeluaran konsumsi juga turun. Tinggi rendahnya pengeluaran sangat tergantung kepada kemampuan suatu keluarga dalam mengelola pendapatan. Idealnya pendapatan yang diterima karyawan akomodasi dan restoran mampu untuk memenuhi kebutuhan konsumsi sehari-hari untuk keluarga. Akan tetapi, adanya erupsi Gunung Agung, kemudian mengakibatkan penurunan pada pendapatan karyawan di sektor pariwisata membuat pola komsumsi karyawan tersebut khususnya yang telah berkeluarga terganggu.

Seperti halnya dalam penelitian ini menemukan bahwa dalam waktu sebulan, karyawan yang biasanya membeli beras sebanyak $25 \mathrm{~kg}$ menjadi berkurang yaitu membeli berasnya berangsur-angsur yakni 2 kg sampai $3 \mathrm{~kg}$, setelah itu habis dikonsumsi baru kemudian membeli lagi. Hal tersebut dikarenakan adanya rasa khawatir dari karyawan untuk hari kedepannya yang belum diketahui akan terjadi hal yang tidak diinginkan seperti sakit atau kecelakaan, jadi harus memang benar-benar keuangannya dikelola dengan baik dan bijaksana sehingga nanti mampu menutupi atau membiayai kejadian aksidental (tidak terduga).

\section{f. Investasi Pendidikan Keluarga Karyawan Pariwisata Ubud}

Pendidikan anak diklasifikasikan menjadi dua, yaitu pendidikan formal dan informal. Pendidikan formal adalah pendidikan yang diterima anak di bangku sekolah, sedangkan pendidikan nonformal biasanya dengan les di luar jam sekolah. Pada bidang pendidikan, menurunya tingkat pendapatan karyawan akomodasi ataupun restoran di Kelurahan Ubud khususnya yang telah berkeluarga berpengaruh terhadap pendidikan anaknya.

Penurunan pendapatan karyawan berpengaruh pada pendidikan anak karyawan tersebut yang bekerja pada usaha akomodasi maupun restoran sehinga beberapa hal harus dipertimbangkan, salah satu implikasinya yaitu biaya pendidikan. Biaya pendidikan yang dimaksud adalah keterlambatan dari karyawan (orang tua) yang membayar biaya pendidikan anaknya di sekolah ataupun tempat les. Seperti pembayaran persemester dan pembelian buku pelajaran untuk anaknya. Hal tersebut terjadi karena karyawan harus memenuhi kebutuhan sehari-hari yang lebih urgent terlebih dahulu, sehingga kehidupan sehari-hari keluarga dan pendidikan anaknya bisa beriringan. Hal tersebut menunjukan bahwa pentingnya kestabilan pendapatan dari karyawan untuk menjunjang kebutuhan pendidikan.

\section{g. Pekerjaan Tambahan bagi Karyawan Pariwisata Ubud}

Adanya pemendekan jam kerja membuat karyawan yang bekerja pada usaha akomodasi dan restoran di Ubud mencari pekerjaan tambahan untuk menutupi kebocoran ekonomi keluarga. Salah satu usaha yang dilakukan yaitu sebagai pedagang sembako. Saat mendapatkan konsekuensi pemendekan jam kerja, karyawan mengisi selah-selah kekosongan waktunya untuk berjualan dengan keluarga. Selain itu, terdapat juga karyawan yang bekerja sebagai petani. Sehinga kebutuhan keluarga dapat terpenuhi. Selain mencari pekerjaan tambahan, waktu rekreasi bersama keluarga juga terganggu.

Rekreasi membuat seseorang merasa lebih fresh dan senang. Kegiatan rekreasi biasanya dilakukan di luar tempat tinggal atau rumah. Setiap orang memiliki waktu dan tempat yang berbeda-beda untuk kegiatan rekreasi. Pada umumnya seseorang berekreasi pada akhir pekan yaitu hari Sabtu dan atau hari Minggu. Ada yang rekreasi dalam satu minggu sekali, dua minggi sekali dan bahkan sebulan sekali. Tempat-tempat yang dituju seperti: pantai, taman rekreasi, toko berbelanja, dan ketempat-tempat suci. Namun, dari hasil penelitian karyawan yang biasanya rekreasi bersama keluarga dalam waktu 
seminggu sekali menjadi tertunda akibat pendapatan yang tidak cukup dianggarkan untuk rekreasi. Karyawan memilih untuk memenuhi kebutuhan sehari-harinya terlebih dahulu dibandingkan rekreasi. Selama lebih kurang dua bulan karyawan tersebut tidak melakukan kegiatan rekreasi bersama keluarganya. Pekerjaan tambahan membuat waktu untuk rekreasi juga semakin sedikit. Jadi, tinggi rendahnya pendapatan karyawan yang bekerja pada restoran akan berpengaruh terhadap kondisi sosial karyawan.

\section{Refleksi dan Analisis}

Implikasi erupsi Gunung Agung pada tahun 2017 mengakibatkan terganggunya sektor usaha pariwisata. Dalam hal ini, peran dan cara pemerintah dalam mengkomunikasikan bencana kepada wisatawan maupun masyarakat menjadi sangat penting. Artinya, pemerintah memberikan informasi yang lebih akurat sehingga wisatawan ataupun masyarakat lebih percaya karena informasi dari pemerintah adalah informasi yang resmi serta sepatutnya untuk dipercaya. Jadi, peran pemerintah dalam membangun citra pariwisata dan melindungi pelaku pariwisata sangat dibutuhkan.

Erupsi Gunung Agung mengingatkan bahwa untuk di masa mendatang agar lebih tanggap bencana. Di samping itu, ke depan juga perlu adanya manajemen krisis dalam penyelesaian krisis, pentingnya mitigasi dalam pencegahan atau mengantisipasi dampak dari bencana khususnya bencana erupsi. Penerapan kebijakan dari pemerintah juga menjadi hal penting dalam memberikan solusi terhadap permasalahan yang ada dari erupsi Gunung Agung terhadap sosial ekonomi pelaku pariwisata, khususnya pada usaha akomodasi dan restoran.

\section{SIMPULAN DAN SARAN}

Berdasarkan hasil penelitian di atas, maka dapat ditarik kesimpulan yakni implikasi erupsi Gunung Agung terhadap sosial ekonomi pelaku usaha akomodasi dan restoran di Kelurahan Ubud yaitu mengakibatkan rendahnya tingkat hunian pada usaha akomodasi, terjadinya penurunan kunjungan ke restoran, terdapat pemendekan jam kerja karyawan baik itu yang bekerja di usaha akomodasi maupun retoran, berkurangnya pendapatan karyawan yang menyesuaikan dengan tingkat kunjungan wisatawan ke restoran atau tingkat hunian pada usaha akomodasi, serta berpengaruh juga terhadap kesejahteraan karyawan yakni pada aspek pola konsumsi, investasi pendidikan dan pekerjaan tambahan bagi karyawan yang bekerja pada akomodasi dan restoran di Kelurahan Unud baik sebagai pedagang ataupun petani.

Adapun saran dalam penelitian ini adalah ditunjukan kepada karyawan akomodasi dan restoran, pelaku usaha akomodasi dan restoran serta pemerintah yakni sebagai berikut.

1. Kepada karyawan yang bekerja di usaha akomodasi dan restoran

Selain untuk bekerja di sektor pariwisata, sebaiknya karyawan tersebut juga mempunyai kerja sampingan di luar sektor pariwisata dan atau memiliki usaha sediri seperti sebagai pedagang.

2. Kepada pelaku usaha akomodasi dan restoran

Diharapkan mampu membuat keputusankeputusan yang bijak berdasarkan pada aspirasi karyawan dan tidak terlalu merugikan karyawan sehingga dapat terciptanya suasana yang harmonis.

3. Kepada pemerintah

Pemerintah diharapkan mampu membuat kebijakan dan publikasi mengenai berita baik dan akurat tentang pariwisata di Kelurahan Ubud pada khususnya agar tetap menjaga rasa aman dan nyaman bagi wisatawan yang sedang berkunjung serta memperketat pengawasan tentang tenaga kerja di sektor pariwisata.

\section{DAFTAR PUS TAKA}

Anonim. 2015. Profil Kelurahan Ubud Tahun 2015.

Arida, I. N. S. 2017. Perencanaan Pariwisata Bekelanjutan Bali Timur: Memaknai Erupsi Gunung Agung. Denpasar: Pustaka Larasan.

Bronto, S. 2001. Volkanologi. Yogyakarta: Sekolah Tinggi Teknologi Nasional Yogyakarta.

Bungin, B. 2007. Penelitian Kualitatif. Jakarta: Kencana.

Damanik, J. dan H. F. Weber. 2006. Perencanaan Ekowisata. Yogyakarta: CV Andi Offset.

Febriaty, H. 2015. Dampak Erupsi Gunung Sinabung terhadap Pendapatan dari Sektor Pariwisata di Kabupaten Karo. Jurnal Ekonomikawan, 15(1).

Islamy, I. 2003. Prinsip-Prinsip Perumusan Kebijaksanaan Negara. Jakarta: Bina Aksara. 
Pujani, L. P. K. 1981. Peranan Agen Asing dalam Kaitannya dengan Pertumbuhan Seni Lukis di Desa Ubud (Sebuah Kajian Antropologi). Denpasar: Universitas Udayana.

Rahmawati, S. dan W. Wirjono. 2014. Dampak Erupsi Terhadap Industri Pariwisata di Kawasan Wisata Gunung Kelud Kabupaten Kediri. Disertasi, Universitas Gadjah Mada.

Rindrasih, E. dan S. Mujiasih. 2015. Bencana Dan Pariwisata: Bagaimana Pariwisata Merespon Cuaca Ekstrim. Jurnal Riset, 2 (1), Pp.54-64.

Rosni, R. 2017. Analisis Tingkat Kesejahteraan Masyarakat Nelayan di Desa Dahari Selebar Kecamatan Talawi Kabupaten Batubara. Jurnal Geografi, 9(1), Pp.53-66.

Sri, A. A. P. 2013. Faktor-faktor yang memotivasi perempuan sebagai pengelola pondok wisata di Kelurahan Ubud Kecamatan Ubud Kabupaten Gianyar. Analisis Pariwisata, 13(1), pp.1-10.

Sunarta, I. N. 2015. Dampak Perkembangan Usaha Akomodasi Terhadap Sumber Daya Air di Kecamatan Kuta Utara Kabupaten Badung Bali. Program Pascasarjana, Universitas Udayana Bali.

Sumber lain:

Anonim. 2017. Erupsi Gunung Agung Jadi Pukulan Telak, 40 Persen Wisatawan Mancanegara Indonesia Ada di Bali. Tersedia pada http://medan.tribunnews.com (diakses pada 9 Desember 2017). 